\title{
INOVASI DUKCAPIL DIGI MOBIL DALAM MENINGKATKAN PELAYANAN PUBLIK PADA DINAS KEPENDUDUKAN DAN PENCATATAN SIPIL KOTA PARIAMAN
}

\author{
Dahlila \\ Peneliti pada Dinas Kependudukan dan Pencatatan Sipil, Kota Pariaman \\ dahlila.map11unp@gmail.com
}

\begin{abstract}
Aldri Frinaldi
Jurusan Ilmu Administrasi Negara, Fakultas Ilmu Sosial, Universitas Negeri Padang, aldri@fis.unp.ac.id
\end{abstract}

\begin{abstract}
Progress in information technology today also modernize various public services including population registration services. Nowadays people always wanted services that were easier and did not need to queue at service counters. To minimize problems related to services, public service providers make innovations in service. The Department of Population and Civil Registration of Pariaman City as the organizer of population document management services has made an internet-based innovation called Dukcapil Digi Mobile which means being served geniusly. By using qualitative research methods and data collection techniques carried out by interviews, observation, and documentation study, the results of this study showed that the Dukcapil Digi Mobile innovation criteria were successful in terms of the success factors in implementing the innovation. Its implementation was influenced by supporting and inhibiting factors.
\end{abstract}

Keywords: Innovation, public services, internet, technology

Submitted: September 28, $2020 \quad$ Reviewed: November 9, $2020 \quad$ Published: November 24, 2020

How to Cite: Dahlila dan Aldri. 2020. Inovasi Dukcapil Digi Mobile dalam Meningkatkan Pelayanan Publik pada Dinas Kependudukan dan Pencatatan Sipil Kota Pariaman. Vol 4 (2): pp. 241-254. DOI: https://doi.org/10.24036/jess.v4i2

\section{Pendahuluan}

Pesatnya pemanfaatan teknologi informasi dan komunikasi dalam kehidupan adalah sesuatu hal yang dinamis. Teknologi informasi senantiasa berkembang mengikuti perubahan zaman. Perubahan identik dengan sesuatu yang baru dan berbeda dengan biasanya. Tidak terkecuali dengan pelayanan publik. Kehadiran Undang-undang Nomor 23 Tahun 2014 tentang Pemerintahan Daerah yang sudah terdapat beberapa kali perubahan, di dalamnya terdapat bahwa penyelenggaraan pemerintahan diarahkan untuk mempercepat terjadinya kesejahteraan bagi masyarakat dalam upaya peningkatan pelayanan, sehingga pemerintah daerah di seluruh Indonesia termasuk pemerintah Kota Pariaman berupaya menghasilkan inovasi untuk menjadikan pelayanan semakin mudah, cepat dan membahagiakan masyarakat. Kemajuan teknologi ikut memodernisasi pelayanan publik termasuk 
dalam pelayanan administrasi kependudukan. Hubungannya dengan pemerintah adalah sebagai bentuk perwujudan penerapan e-governnance dalam tata kelola pemerintahan yang baik yang mampu menceminkan citra pemerintahan.

Potret pelayanan publik di tanah air sangat beragam. Hal ini juga ditanggapi berbeda oleh masyarakat selaku pengguna layanan publik. Pelayanan tidak mudah dilakukan, sulit diakses, prosedur berbelit, terkadang memunculkan calo serta terjadinya praktek pungutan liar (pungli). Selain itu ada kecendrungan yang lebih menonjolkan ketidakadilan dalam pelayanan pada masyarakat. Hal ini juga untuk mengantisipasi kemungkinan banyaknya antrian pada loket pelayanan. Bahkan di beberapa pelayanan publik ada yang secara terinci mencantumkan biaya pelayanan dan ada yang tidak menjelaskan tetapi tetap memungut biaya.

Berdasarkan observasi awal di Disdukcapil Kota Pariaman yang dilakukan terhadap beberapa masyarakat yang datang dalam pengurusan dokumen penambahan anggota keluarga sekaligus penerbitan Akte Kelahiran ditemukan permasalahan bahwa masyarakat yang datang pada sekitar Pkl. 11.30 WIB siang harus kembali dengan alasan sudah siang. Petugas menerangkan bahwa sudah banyak antrian dan menyarankan untuk datang kembali setelah jam istrirahat selesai. Namun terhadap masyarakat yang punya hubungan baik dengan petugas yang lainya. Bisa menitipkan berkas dan bahkan bisa ditunggu penyelesaianya.

Menyikapi ketidakmerataan dan ketidakadilan yang terjadi ini, maka keberpihakan pelayanan seperti ini bisa memunculkan potensi yang bersifat membahayakan kehidupan berbangsa dan bernegara. Memicu kecemburuan dan semakin berkurangnya kepercayaan masyarakat pada pelayanan publik. Saat ini masyarakat hanya menginginkan pelayanan yang lebih mudah dan tidak perlu melakukan antrian di loket-loket pelayanan. Hal yang sering dikeluhkan adalah proses dan prosedur yang lama. Antrian yang banyak dengan pembatasan jam pelayanan. Terkadang masyarakat yang sudah menyediakan waktu seharian dari memulai pendaftaran, seringkali masih harus berulang karena terkait kelengkapan berkas atau terbatasnya waktu pelayanan, hingga harus melakukan pelayanan pada hari berikutnya.

Program inovatif atau pembaharuan dikembangkan guna mengantisipasi segala kemungkinan kekurangan dan menganalisa serta menganti program yang sudah usang atau kurang update. Pembaruan dimaknai dengan penggantian sistem birokratis menjadi sistem yang bersifat business entity. Oleh karena itu, tuntutan terhadap inovasi pelayanan publik sangat diperlukan demi mendekatkan diri dan lebih menciptakan kemudahan menjadi prioritas. Salah satu usaha menjawab tuntutan ini maka Inovasi dalam pelayanan publik diciptakan guna kemudahan pengguna untuk mengakses segala keperluannya dalam pelayanan publik. Pelayanan publik berbasis teknologi informasi perlu diterapkan untuk mengurangi resiko terjadinya antrian dalam memberikan pelayanan, dan ketidakpastian mengenai waktu ataupun biaya pelayanan. Teknologi informasi menjadi solusi dalam permasalahan sehingga pelayanan publik menjadi lebih efektif dan efisien. Pelayanan publik berbasis teknologi informasi perlu diterapkan untuk mengurangi resiko terjadinya kecurangan dalam memberikan pelayanan, dan ketidakpastian mengenai waktu ataupun biaya pelayanan dan tentunya mengurangi calo atau kemungkinan pungutan liar. 
Di Kota Pariaman khususnya Disdukcapil sudah diterapkan pelayanan dengan memanfaatkan teknologi informasi. Namun pelayanan ini belum begitu dimanfaatkan masyarakatnya. Salah satu inovasi yang dikembangkan untuk meningkatkan kualitas pelayanan administrasi adalah inovasi teknologi berbasis internet yaitu http://dukcapildigi.go.id yang dinamakan dengan Dukcapil Digi Mobile. Pentingnya inovasi diharapkan menjadi skala nasioanal dan berkelanjutan. Dengan pemilihan Top Inovasi pelayanan publik 2019 dan mendapatkan alokasi Dana Insentif Daerah (DID) yang dijaring KemenpanRB harusnya memicu instansi dalam berinovasi.

Kurangnya pengetahuan masyarakat Kota Pariaman terkait perkembangan teknologi informasi menjadi kendala terhadap berjalannya Dukcapil Digi Mobile. Banyak masyarakat yang belum mengetahui adanya aplikasi ini. Belum adanya pegawai khusus yang ditunjuk. Selain itu jaringan internet juga menjadi faktor penghambat. Fenomena ini memicu peneliti tertarik untuk mengetahui dan memahami lebih dalam wujud penyelenggaraan pelayanan berbasis teknologi informasi ini melalui penelitian dengan judul: Inovasi Dukcapil Digi Mobile Dalam Meningkatkan Pelayanan Publik pada Dinas Kependudukan dan Pencatatan Sipil Kota Pariaman. Tujuan penelitian adalah untuk menganalisis penerapan inovasi Dukcapil Digi Mobile dalam meningkatkan pelayananan masyarakat Kota Pariaman. Selain itu juga untuk mengidentifikasi faktor pendukung dan faktor penghambat inovasi Dukcapil Digi Mobile dalam meningkatkan pelayananan publik Kota Pariaman.

\section{Tinjauan Kepustakaan}

\section{Inovasi dalam Pelayanan Publik}

Menurut Ancok (dalam Puspasari \& Ra'is, 2019) inovasi merupakan proses memaknai dan menerapkan suatu gagasan, ide yang memuat pembaharuan dalam mengelola berbagai urusan masyarakat banyak. Sedangkan dalam Permenpan dan Reformasi Birokrasi No. 30 Tahun 2014 Tentang Pedoman Inovasi Pelayanan Publik serta Kebutuhan Inovasi LAN inovasi merupakan proses kreatif penciptaan pengetahuan dalam melakukan suatu penemuan baru yg berbeda dan/atau modifikasi dari yang sudah ada. Sedangkan Damanpour (dalam Prianto \& Sumantri, 2020) mendefinisikan bahwa wujud inovasi dapat berupa produk atau jasa yang baru, teknologi proses produksi yang baru, sistem struktur dan administrasi baru atau rencana baru bagi semua anggota organisasi. Inovasi adalah memperkenalkan ide baru, barang baru, pelayanan baru dan cara-cara baru yang lebih bermanfaat. Menurut Amabile (dalam Ramadhan, 2016) inovasi menunjukan adanya perubahan yang dirasakan sebagai hal yang baru oleh masyarakat yang mengalami.

Kesimpulanya pemaknaan inovasi dalam administrasi publik bertujuan agar dapat menjawab beragam persoalan dalam tata kelola kepemerintahan, termasuk dalam peran pemerintah untuk pelayanan yang baik dan perwujudan kinerja organisasi pemerintahan. Ancok (dalam Rusmiarti, 2015) membagi jenis-jenis Inovasi sebagai berikut: (1) Inovasi proses; yaitu suatu upaya mengkreasikan dan mengembangkan suatu proses kerja agar menjadi semakin lebih sederhana dan 
efektif, dimana permasalahan dewasa ini umumnya proses kerja yang lambat dan berbelit-belit; (2) Inovasi metode; inovasi ini dimaksudkan agar cara dalam melakukan sesuatu, yang memiliki berbagai bentuk, sektor, dan dimensi; (3) Inovasi struktur organisasi; inovasi yang diarahkan pada organisasi untuk melakukan pembaruan dalam struktur organisasinya agar fleksibel menghadapi lingkungan dan kemungkinan yang belum bisa diprediksi; (4) Inovasi dalam hubungan; inovasi ditujukan pencapaian tujuan organisasi dengan pola hubungan dengan lingkungan luar dalam cara yang inovatif, saling menguntungkan, dan saling memampukan; (5) Inovasi strategi; inovasi yang dimaksudkan untuk menciptakan berbagai strategi yang menciptakan langkah-langkah strategis pencapaian tujuan organisasi; (6) Inovasi pola pikir (mindset); inovasi yang diupayakan untuk merangsang perubahan pola pikir sumber daya manusia; (7) Inovasi produk; yaitu inovasi yang dirancang untuk proses kerja pada suatu organisasi berwujud jenis yakni fisik (barang) dan non-fisik atau imateriel (jasa), agar bentuk inovasi memiliki tingkat saing yang tinggi dan membuat konsumenya puas.

Produk baru atau pembaruan yang dibuat perlu diperkenalkan agar produk tersebut diterima dan digunakan oleh masyarakat secara luas. Menurut Roger (dalam Puspasari \& Ra'is, 2019) keberhasilah suatu inovasi tergantung pada beberapa kriteria sebagai berikut: 1) Karaktersitik Inovasi; Sebuah produk atau hasil inovasi dapat dengan mudah diterima masyarakat jika inovasi tersebut memiliki kelebihan yang relatif. Faktor jenis produk lain berupa kemampuan untuk dilirik masyarakat berpengaruh terhadap hasi inovasi, yaitu mampu memenuhi kebutuhan, nilai-nilai dan keinginan konsumen secara konsisten; 2) Saluran Komunikasi; Saluran komunikasi merupakan media yang mampu menyebarkan informasi kepada masyarakat lainya, seperti keberadaan provider; 3) Upaya Perubahan dari Agen; Dalam upaya memasyarakat inovasi atau produk harus melibatkan agen yang berkualitas dan mampu mempengaruhi dan membawa masyarakat untuk menerima dan menggunakan produk baru (inovasi); dan 4) Sistem Sosial; Sistem sosial dalam masyarakat atau kaum milenial akan cendrung mau menerima perubahan yang positif dan menghargai kemajuan. Lewat inilah ide akan suatu inovasi akan mudah diterapkan.

Selanjutnya, menurut Kemenpan No. 63/KEP/M.PAN/7/2003, pelayanan publik merupakan semua kegiatan dalam pemenuhan kebutuhan penerima pelayanan maupun pelaksanaan ketentuan peraturan perundang-undangan. Artinya, pelayanan publik adalah pemenuhan keinginan dan kebutuhan masyarakat oleh pelaksana pelayanan publik. Selanjutnya Menurut Kurniawan (dalam Atthahara, 2018) pelayanan publik dimaknai dengan kegiatan melayani keperluan orang atau masyarakat yang berurusan pada instansi penyelenggara pelayanan publik sesuai dengan peraturan yang ditetapkan. Sementara pelayanan publik menurut Mahmudi (dalam Puspasari \& Ra'is, 2019) merupakan serangkaian kegiatan atau proses pelayanan yang dilaksanakan oleh instansi pelaksana pelayanan dalam upaya pemenuhan kebutuhan publik sesuai peraturan perundang-undangan.

Menurut Muluk (dalam Wulandari, 2020) inovasi merupakan suatu hal yang sangat penting untuk dilakukan instansi pemerintahan untuk meningkatkan kualitas pelayanannya. Sejalan dengan Kurniawan (2016) bahwa inovasi mengacu pada 
peningkatan pelayanan publik dengan menerapkan berbagai metode kebijakan dan juga berlakunya sejak tahun 2014 adalah tahun inovasi pelayanan publik. Seluruh instansi pemerintah, baik di pusat maupun daerah diharapkan dapat membuat suatu ide kreatif atau jawaban terhadap cara kerja/metode pelayanan publik

Sebuah inovasi adalah suatu pemikiran baru untuk mempermudah serta meningkatkan kualitas pelayanan publik, dan inovasi dalam pelayanan publik tentu tidak keluar dari UU No. 25 Tahun 2009 tetap memegang asas-asas pada bentuk pelayanan publik. Bentuk asas-asas pelayanan publik menurut Pasal 4 UndangUndang Nomor 25 Tahun 2009 yaitu: kepentingan umum, kepastian hukum, kesamaan hak, keseimbangan hak dan kewajiban, keprofesionalan, partisipatif, persamaan perlakuan/tidak diskriminatif, keterbukaan, akuntabilitas, fasilitas dan perlakuan khusus bagi kelompok rentan, ketepatan waktu, dan kecepatan, kemudahan, dan keterjangkauan.

\section{Pelayanan Publik Berbasis Elektronik}

Dalam memenuhi kebutuhan masyarakat pemerintah dapat memanfaatkan perkembangan teknologi informasi yang mana teknologi tersebut digunakan sebagai pelayanan yang efektif dan efisien. Instruksi Presiden No. 3 Tahun 2003 tentang Kebijakan dan Strategi Nasional Pengembangan e-government menjelaskan bahwa e-government merupakan upaya untuk mengembangkan penyelenggaraan kepemerintahan yang berbasis (menggunakan) elektronik dalam rangka meningkatkan kualitas layanan publik secara efektif dan efisien.

Tujuan e-government adalah untuk memperbaiki mutu/kualitas pelayanan publik untuk menciptakan kepuasan masyarakat karena dari segi waktu dengan memberikan suatu kemudahan akses jaringan. Menurut Kementrian Kominfo egovernment lebih sabagai aplikasi teknologi informasi berbasis internet dengan perangkat digital lainnya yang dikelola pemerintah agar keperluan penyampaian informasi dari pemerintah kepada masyarakat dan stakeholder lainya secara online. Menurut Conrad (dalam Fahlefi, 2014) e-government adalah suatu istilah yang diberikan untuk suatu pemerintahan yang mengadopsi teknologi yang berbasis internet yang dapat melengkapi dan meningkatkan program dan pelayanannya. Tujuan utamanya adalah untuk memberikan sesuatu yang lebih baik kepada pengguna jasa atau memberikan kepuasan maksimal.

Konsep pelayanan dengan menggunakan teknologi informasi diharapkan mampu membawa sistem pemerintahan ke arah yang semakin efisien, efektif, transparan dan akuntabilitas, seperti yang tertuang pada kerangka e-government. $E$ Government dianggap sebagai bentuk penyederhanaan praktek pemerintahan dengan memanfaatkan teknologi informasi dan komunikasi. Penerapan EGovernment di Indonesia diawali dengan instruksi Presiden Nomor 6 Tahun 2001 pada tanggal 24 April 2001 tentang Telematika (Telekomunikasi, Media dan Informatika) yang menyatakan bahwa pemerintan harus menggunakan teknologi telematika untuk mendukung good governance.

Menurut Indrajit (dalam Atthahara, 2018) untuk menerapkan konsep-konsep digitalisasi pada sektor publik, ada tiga elemen sukses yang harus dimiliki dan diperhatikan sungguh-sungguh. Masing-masing elemen sukses tersebut adalah: 
a. Support Element; support elemen paling penting dalam pengembangan egovernment. Perlu dukungan atau biasa disebut political will dari pejabat publik agar konsep e-government dapat diterapkan. Tanpa adanya itu berbagai inisiatif pembangunan dan pengembangan e-government dapat terlaksana. Bentuk dukungan yang dapat dilakukan adalah sebagai berikut: Disepakatinya kerangka e-government sebagai salah satu kunci sukses negara dalam mencapai visi dan misi bangsanya, sehingga harus diberikan prioritas tinggi. Disosialisasikannya konsep e-government secara merata, kontinu, konsisten, dan menyeluruh kepada seluruh kalangan birokrat secara khusus dan masyarakat secara umum melalui berbagai cara kampanye yang simpatik.

b. Capacity Element; capacity element merupakan sumber daya yang diperlukan dalam pembangunan dan pengembangan e-government agar konsep yang telah diciptakan dapat menjadi kenyataan. Terdapat tiga sumber daya yang harus dimiliki, yaitu: Ketersediaan sumber daya finansial yang cukup untuk melaksanakan berbagai inisiatif e-government. Ketersediaan infrastruktur teknologi informasi yang memadai karena merupakan 50\% dari kunci keberhasilan penerapan e-government. Ketersediaan sumber daya manusia yang memiliki kompetensi dan keahlian yang dibutuhkan agar penerapan egovernment dapat sesuai dengan asas manfaat yang diharapkan.

c. Value Element; value berdasarkan pada manfaat yang didapat oleh pemerintah sebagai pemberi pelayanan dan juga masyarakat sebagai penerima pelayanan e-government. Dalam elemen value yang menentukan besar tidaknya manfaat e-government adalah masyarakat sebagai penerima pelayanan. untuk itu, perlu ketelitian dalam memilih aplikasi yang menjadi prioritas kebutuhan masyarakat yang perlu didahulukan dalam pembangunan dan pengembangannya.

\section{Metode Penelitian}

Penelitian ini memakai metode penelitian kualitatif. Penelitian dilakukan pada Disdukcapil Kota Pariaman. Dalam penelitian ini digunakan teknik purposive sampling, dimana peneliti menentukan pengambilan sampel dengan cara menetapkan alasan tertentu dalam pengambilan sampelnya sehingga diharapkan dapat menjawab permasalahan yang diteliti. Orang terpilih menjadi informan adalah orang-orang juru kunci yang memiliki informasi mendalam tentang tema yang diteliti. Data primer dalam penelitian ini diperoleh langsung dari informan yang mengetahui informasi yang diteliti, yaitu: Kabid PIAK dan PD selaku penggagas Dukcapil Digi, Kasi Kerjasama dan Inovasi Pelayanan Disdukcapil, Admin aplikasi Dukcapil Digi, Staf pelayanan dan Masyarakat/pengguna Kota Pariaman sebanyak 8 orang. Sementara data sekunder yang digunakan adalah literatur yang relevan, seperti buku-buku referensi, laporan penelitian, dan artikelartikel yang dilaporkan melalui jurnal.

Pengumpulan data dalam penelitian ini dilakukan melalui wawancara dengan informan. Peneliti mencoba menggali data yang lebih lengkap dari informan yang sengaja dipilih yang dirasa cukup mewakili dalam menjawab pertanyaan. 
Informan tersebut, selain itu data juga didapatkan melalui observasi. Observasi dalam hal ini dilakukan untuk mengetahui kriteria pelaksanaan inovasi Dukcapil Digi di Disdukcapil Kota Pariaman. Selanjutnya data juga dikumpulkan melalui studi dokumentasi. Analisis data dalam penelitian ini dilakukan dengan model analisis interaktif, yaitu dengan tahap (1) Reduksi data, dengan merangkum, memilih hal-hal pokok, menjadi satu bentuk tulisan yang akan dianalisis; (2) Penyajian data; dengan menulis ulang kembali dengan penyederhanaan kata sesuai yang dibutuhkan dalam bentuk uraian singkat; dan (3) Penarikan Kesimpulan/verifikasi, berisi uraian keseluruhan.

\section{Hasil dan Pembahasan}

Disdukcapil Kota Pariaman adalah instansi yang menangani pelayanan pengurusan dokumen kependudukan. Dalam rangka menyapa masyarakat secara lebih dekat serta dalam upaya menciptakan pelayanan yang membahagiakan masyarakat Disdukcapil menggagas suatu inovasi pelayanan yaitu Dukcapil Digi Mobile. Ketentuan pelaksanaan Digi Mobile tertuang dalam Surat Keputusan Kepala Disdukcapil No.14 Tahun 2019. Pelaksanaan inovasi Digi Mobile pada Disdukcapil Kota Pariaman yang diterapkan pada pelayanan adalah dalam upaya untuk mengatasi antrian dalam pelayanan.

Ditinjau dari kriteria keberhasilan suatu inovasi, ada 4 hal yang mempengaruhi keberhasilan inovasi tersebut. Menurut Rogers (dalam Bela, 2019) hal-hal yang mempengaruhi inovasi adalah sebagai berikut.

1) Karakteristik inovasi (produk); Dalam pelayanan publik, suatu produk atau hal baru dapat diterima oleh pengguna layanan (masyarakat) jika hal itu terdapat suatu kemudahan dan mempunyai nilai fleksibel dari standar biasanya. Dukcapil Digi Mobile merupakan sebuah penampilan pelayanan publik yang baru, yakni dengan menggunakan sistem pendaftaran online dengan mengentri data dan mengupload berkas syarat yang diajukan dalam kepengurusan dokumen kependudukan. Kemudahan masyarakat dalam melakukan permohonan pelayanan administrasi kependudukan. Kemudahan akses proses permohonan pelayanan dapat dilakukan dimana saja dan kapan saja, dengan hanya mengirim bukti foto berkas permohonan. Selain itu kehadiran Dukcapil Digi Mobile dalam peningkatan data pendaftaran kependudukan yang dalam antrian panjang dapat terkendali. Terkait dengan perbedaan perlakuan dalam pelayanan publik hal ini sangat membantu dan lebih memanfaatkan teknologi dalam mengajukan permohonan melalui pelayanan online. Siapapun dapat dengan leluasa mengirim berkas pendaftaran secara online. Hanya saja masih terdapat masyarakat yang belum mengetahui aplikasi Dukcapil Digi Mobile. Kemudahan selanjutnya Dukcapil Digi tidak terbatas hanya proses pendaftaranp online tetapi tersedia 11 (sebelas) fitur yang mudah digunakan seperti cek stok blanko, cek status KTP, Pengaduan, Persyaratan Dokumen, akta kelahiran, akta kematian, perubahan Kartu Keluarga, Pindah Domisili, Indek kepuasan masyarakat, anggota Kartu Keluarga dan Histori Pelayanan. Jadi sekali membuka bisa melakukan beberapa pengecekan lainnya. Selain itu 
Dukcapil Digi punya server tersendiri jadi memungkinkan untuk lalu lintas data yang cepat.

2) Sarana komunikasi; Inovasi lebih cepat dipahami masyarakat melalui sosialisasi. Sosialisasi dimaksud tidak sebatas pada informasi pada radio, brosur dan web tetapi diperkenalkan dan dipraktekkan pada perangkat desa dengan panduan singkat. Disdukcapil Kota Pariaman bisa memfasilitasi Perangkat desa karena mereka yang dekat dan sering berurusan maka jika sosialisai diefektifkan pada perangkat desa ini maka kemudahan akan lebih cepat dirasakan masyarakat. Sosialisasi bentuk lainya adalah dengan adanya forum Dukcapil Menyapa Masyarakat (DMM), sebagai bentuk pelayanan menyapa masyarakat melalui Zoom, disini seluruh masyarakat bisa bergabung diperkenalkan lebih jauh Dukcapil Digi. Sosialisasi bentuk lainya adalah dengan grup Whatshap, dengan WA, mengirim informasi kepada masyarakat lain semudah melentikan tangan. Meskipun begitu belum banyak masyarakat yang mengetahui Dukcapil Digi Mobile ini.

3) Upaya perubahan dari agen; Disdukcapil Kota Pariaman dalam program inovasi ini memanfaatkan dan menfasilitasi beberapa hal antara lain:

a) Perangkat desa sebagai alternatif terdekat dengan mayarakat. Perangkat desa adalah pihak yang mengetahui karakteristik masyarakatnya sendiri tentu akan mudah menyampaikan keberadaan dan kemudahan Dukcapil Digi Mobile

b) Adanya kerjasama antar pihak-pihak tertentu. Dimana kerjasama ini melibatkan beberapa pihak satu kesatuan dari suatu organisasi dengan masyarakat. Diantaranya kerjasama dengan Pihak rumah Sakit Aisyiah, Tamar Medical Center, klinik dan rumah bersalin. Bentuk kerjasama yang dilakukan melalui pelatihan petugas Dukcapil Digi Mobile yang ada di rumah sakit atau klinik dan rumah bersalin. Ketika ada kelahiran maka petugas ini langsung mendaftarkan berkas dokumen untuk keperluan penambahan anggota dalam Kartu Keluarga sekaligus mendaftarkan proses pembuatan Akte Kelahiran anak yang bersangkutan.

c) Sumber daya manusia yang mendukung; Sumber Daya manusia diantaranya Admin Dukcapil Digi Mobile dan Operator (petugas pelayanan) dengan kualifikasi pendidikan dan kompetensi bidang yang berhubungan dengan Teknologi, sehingga sangat paham dengan seluk beluk dunia Teknologi Informasi. Petugas akan cepat meresepon dengan kelincahan pengalaman dan kemahiran berteknologi. Dukcapil bisa memanfaatkan Tim SK Inovasi utntuk bekerja maksimal. Untuk memproses permohonan pendaftaran dengan penarikan data dan langsung menerbitkan dokumen cetaknya untuk kemudian diantarkan pada pihak Rumah Sakit/Klinik. Di masa kondisi Pandemi Disdukcapil lebih mengefektifkan kerjasama dengan Kantor Pos untuk pengiriman dokumen yang telah diterbitkan. 
d) Hal lain adalah dengan terbitnya Permendagri No. 109 Tahun 2019 yang mengatur bahwa semua dokumen kependudukan penerbitanya dilakukan menggunakan kertas Putih A4 80 gram. Hal ini semakin mempengaruhi pelaksanaan Inovasi Digi Mobile, karena tadinya butuh waktu dan blanko dalam pencetakan. Tetapi semenjak kehadiran Permendagri ini semakin menunjukan kemudahan aksesnya. Terlebih sewaktu masyarakat merasa dokumen hilang atau rusak bisa dicetak kembali di rumah karena sudah adanya file dikirim melalui email.

4) Sistem sosial; Pada hakekatnya masyarakat yang cepat dalam menerima inovasi adalah pada kaum milenial. Kaum milenial adalah masyakarat produktif yang terbiasa dengan penggunaan teknologi informasi. Dilihat dari jumlah penduduk Kota Pariaman setengahnya adalah usia produktif. Usia produktif adalah kaum yang sangat melek dengan teknologi.

Pelaksanaan Dukcapil Digi Mobile dalam usaha peningkatan pelayanan publik dapat dikatakan efektif, karena pelaksanaan Dukcapil Digi adalah solusi dan jawaban alternatif dari peroses pengurusan dokumen kependudukan secara daring atau online. Dokumen pengurusan Dukcapil Digi berupa kemudahan pengurusan dokumen kependudukan dimana masyarakat cukup melakukan dari tempat lain dengan mengupload dokumen dan langsung akan diproses hingga penerbitan diantar ke rumah oleh Kantor Pos hingga sampai pada tangan masyarakat. Masyarakat cukup menunggu di rumah. Dengan demikian dalam pengurusan dokumen kependudukan Dukcapil Digi dalam peningkatan pelayanan publik dapat dikategorikan efektif karena telah memangkas birokrasi pelayanan.

Sebagai salah satu upaya peningkatan pelayanan publik oleh Dukcapil Digi Mobile, maka pelaksanaanya dipengaruhi oleh faktor pendukung dan faktor penghambat. Faktor pendukung digambarkan sebagai sesuatu hal yang membuat pelaksanaan inovasi tepat sasaran dalam mendekatkan pelayanan pada masyarakat. Faktor yang menjadi penghambat dalam proses inovasi adalah hal-hal yang membuat Aplikasi Dukcapil Digi menemui kendala dalam proses pengurusan dokumen kependudukan.

Faktor pendukung Disdukcapil Digi Mobile dalam meningkatkan pelayanan publik adalah keunggulan dari inovasi tersebut yaitu cara mengakes Dukcapil Digi Mobile sangat mudah, tidak membutuhkan waktu yang lama dalam mendaftarkan berkas cukup dengan mengupload bukti foto persyaratan. Selain itu terdapat langkah pengoperasian Dukcapil Digi dengan banyak opsi fitur menu yang bisa di pilih oleh masyarakat. Faktor pendukung lainnya adalah faktor sosial opsi produk layanan, yaitu brosur yang berisi persyaratan dan tata cara dan langkah untuk bisa menikmati Digi Mobile. Faktor pendukung lainya adalah bahwa inovasi ini digagas oleh sumber daya internal Disdukcapil Kota Pariaman. Inovator internal ini tentu akan lebih menghemat anggaran dan sudah diuji cobakan, serta dikuasai oleh seluruh petugas pelayanan.

Sementara faktor penghambat dalam inovasi Disdukcapil Digi Mobile ini antara lain: 
1) Infrastruktur teknologi sinyal dan jaringan; apalagi kalau cuaca kurang bersahabat maka sinyal hilang, maka aplikasi tidak dapat diakses sama sekali. Untuk beberapa daerah Kota Pariaman tidak semua bisa menangkap sinyal dengan baik. Banyak daerahnya sulit menemukan sinyal provider dengan baik. Terlebih untuk daerah di Kecamatan Pariaman Timur, seperti Kampung Baru Padusunan, Kampung Kandang dan Talago Sarik. Padahal secara georagfis terletak masih dalam area perkotaan dimana ada Tower Telkomsel. Daerah lain di Kecamatan Pariaman Utara seperi Tungkal Utara, Tunggal Selatan dan Cubadak Air, juga susah menerima sinyal.

2) Terkait dengan waktu dan jam kerja pegawai jam kerja juga dirasa menjadi kendala. Jam kerja pegawai hanya sampai hari jumat. Kalaupun ada permohonan yang masuk aplikasi maka akan dilayani pada hari kerja. Belum ada petugas khusus dalam menangani jika terjadi kendala.

3) Hal lain yang cukup terasa adalah kebiasaan masyarakat Kota Pariaman sendiri yang terbiasa melakukan pelayanan tatap muka dan belum terbiasa dalam aplikasi ini. Masyarakat kalau tidak terpaksa maka enggan mencoba. Kalau tidak terdesak masyarakat tidak akan mengurus dokumennya. Hal lainya yang menghambat adalah bahwa masyarakat belum punya email untuk aktivasi login dan membuat akun pendaftaran. Padahal banyak masyarakat mengakses media sosial seperti facebook dan WA.

4) Kondisi lainya adalah adanya perantara pengurusan atau calo. Karena masyarakat enggan melakukan pengurusan dan jika sudah sangat terdesak maka masyarakat memanfaatkan perantara atau calo pengurusan. Kondisi ini akan menimbulkan fenomena lain tentang pengurusan dokumen terkait munculnya biaya pengurusan. Padahal semenjak berlakunya Perda No. 18 Tahun 2018 tentang penghapusan denda, semua pengurusan dokumen tidak berbayar.

Upaya yang dapat dilakukan terhadap faktor penghambat pelaksanaan Digi Mobile pada Disdukcapil Kota Pariaman:

1. Memperbaiki sistem jaringan. Disdukcapil bisa meningkatkan kerjasama dengan Pihak Dinas Komunikasi dan Informasi (Kominfo) dan pihak telkomsel untuk mengatasi kendala. Bisa dengan permintaan khusus untuk beberapa daerah yang sulit menjangkau jaringan.

2. Terkait dengan jam pelayanan aparatur Disdukcapil bisa melakukan pengaturan sistem kerja pelayanan dengan sistem sif. Pembagian sistem kerja dimana kalaupun ada permohonan yang sudah masuk tetap akan diproses. Beberapa petugas yang diberi akses VPN bisa melakukan proses pengentrian pada permohonan aplikasi SIAK di luar lingkungan Disdukcapil. Ini akan sangat membantu sekali terkait keterbatasan jam kerja. Tentu dengan metode yang bisa dibicarakan secara internal.

3. Terkait dengan kebiasaan masyarakat Kota Pariaman yang sudah lebih suka dan terbiasa melakukan pelayanan tatap muka bisa dilakukan sosialisasi jemput bola dengan mendatangi keluarahan/Desa untuk mensosialisasikan Digi 
Mobile. Sosialisasi bisa dengan mendatangi masyarakat secara langsung atau dengan menempelkan pengumuman pada Kantor Desa/Kelurahan. Atau selama masa pandemi bisa mengefektifkan Zoom Dukcapil Menyapa Masyarakat (DMM) bukan hanya sebulan sekali tetapi bisa diupayakan 3 kali dalam sebulan.

4. Semenjak berlakunya Perda No. 18 Tahun 2018 semua dokumen pengurusan sudah tidak memungut biaya. Dengan Digi Mobile masyarakat tidak perlu lagi melakukan pengurusan lewat orang lain. Semuanya bisa dilakukan dirumah. Hanya saja masyarakat harus diarahkan punya email sendiri.

Berdasarkan unsur-unsur yang mendukung dan penghambat lajunya inovasi, bisa dipahami bahwa upaya pelaksanaan Dukcapil Digi dengan kriteria keberhasilan inovasi dikatakan cukup menjadi andalan dan perlu dikembangkan lebih lanjut. Hasil penelitian ini didukung dengan penelitian Kofi (2019) Inovasi Pelayanan Pembuatan SIM di Polres TTU bahwa inovasi efektif ditandai dengan adanya terobosan-terobosan baru peningkatan pelayanan dengan rekomendasi dukungan anggaran. Hal ini sangat sejalan dengan penelitian yang dilakukan Pamungkas \& Handayaningsih (2014) bahwa implementasi aplikasi e-Government di Pemerintah Kota Yogyakarta memberikan kemudahan kepada masyarakat. Penelitian ini juga sejalan dengan hasil penelitian Jananto \& Yuliaton (2016) bahwa layanan publik berbasis meta mobile dikategorikan berhasil karena kemudahan dan hasil nyata. Penelitian lainnya yang dilakukan pada nagari daerah Padang Panjang yang menghasilkan bahwa inovasi mampu menjadikan proses layanan dapat diselesaikan dengan cepat dan mudah walaupun masih ada kendala yang menghambat (Jalma, Putra, and Kusdarini 2019).

Suatu inovasi dalam perjalanannya tentu ada yang membuatnya untuk tidak secepat kilat menjadi perubahan yang dituju. Justru dengan berbagai faktor mempengaruhi adalah upaya seleksi yang akan membuat inovator lebih tertantang dalam melakukan tahap selanjutnya. Sekaligus sebagai awal evaluasi untuk langkah yang diambil untuk pemenuhan kebutuhan selanjutnya. Inovasi tidak akan berjalan kalau hanya berencana.

\section{Penutup}

Berdasarkan pembahasan teori inovasi dalam pelayanan publik dengan pemanfaatan media internet maka pelaksanaan inovasi Dukcapil Digi (Digi Mobile) dalam upaya meningkatkan pelayanan publik pada Disdukcapil Kota Pariaman dapat dikemukakan beberapa kesimpulan yaitu:

1. Penerapan Inovasi Digi Mobile dalam meningkatkan pelayanan publik Pada Dispenduk Kota Pariaman yang mulai Juni 2019 secara konsep inovasi dapat dikatakan memenuhi kriteria berhasil dan dikatakan efektif dan efisien karena sudah terdapat 4 faktor yang akan mempengaruhi keberhasilan penyelenggaraan inovasi. Keempat faktor tersebut antara lain: Karakteristik Inovasi (Produk) yaitu kemudahan mendownload aplikasi, terdiri dari 11 (sebelas) menu pilihan dalam pengurusan dokumen; faktor saluran komunikasi 
berupa kemudahan akses; faktor upaya perubahan dari agen berupa menfasilitasi perangkat desa; dan faktor sistem sosial, dimana terjadinya penerimaan yang cepat oleh generasi milenial.

2. Faktor pendukung inovasi Disdukcapil Digi mobile antara lain akses yang sangat mudah dalam pengoperasian, masyarakat tidak perlu lagi datang dan antri di loket akan menghilangkan calo dalam pengurusan dokumen calo. Disdukcapil Kota Pariaman cukup mendaftar online. Hal ini sangat menguntungkan bagi masyarakat yang berada di luar daerah domisili. Sedangkan faktor yang menghambat adalah inftrastruktur jaringan dan sinyal provider, persoalan jam kerja pegawai hanya 5 hari dalam seminggu, keengganan masyarakat melakukan pengurusan kalau tidak terpaksa dan juga masih kurangnya pengetahuan terkait teknologi dan masih adanya calo pengurusan dokumen.

\section{DAFTAR KEPUSTAKAAN}

Atthahara, Haura. 2018. "Inovasi Pelayanan Publik Berbasis E-Government : Studi Kasus Aplikasi Ogan Lopian Dinas Komunikasi Dan Informatika Di Kabupaten Purwakarta.” Jurnal Politikom Indonesiana 3(1):66-77.

Bela, Puspasari. 2019. "Inovasi Anjungan Tunai Mandiri (ALM) Dalam Meningkatkan Pelayanan Publik (Studi Di Kelurahan Belimbing Kecamatan Belimbing Kota Malang).” JISIP: Jurnal Ilmu Sosial Dan Ilmu Politik 8:1-8.

Fahlefi, Zul. 2014. "Penerapan Teknologi Informasi Bagi Pelaksanaan Pelayanan Publik (Studi Kasus Pada BP2TSP Kota Samarinda).” Jurnal Paradigma 3(2):155-66.

Jalma, Hazid, Roni Ekha Putra, and Kusdarini. 2019. E-Government Dengan Pemanfaatan Web OpenSID Dalam Pelayanan Publik Di Nagari Tanjung Haro Sikabu-Kabu Padang Panjang. Publik (Jurnal Ilmu Administrasi), 8 (1).

Jananto, Arief, and Heribertus Yuliaton. 2016. "Public Service Information Based on Map-Mobile as A Guide Search Places Public Service in Semarang City (Informasi Layanan Publik Berbasis Peta Mobile Sebagai Panduan Pencarian Tempat Layanan Masyarakat Di Kota Semarang)." Journal Pekommas 1(1):69. doi: 10.30818/jpkm.2016.2010107.

Kofi, Herminus. 2019. Inovasi Pelayanan Pembuatan SIM Di Polres TTU Kabupaten Timor Tengah. Jurnal Ilmiah Manajemen Publik dan Kebijakan Sosial. 3 (2), 414-34.

Kurniawan, Robi Cahyadi. 2016. "Inovasi Kualitas Pelayanan Publik Pemerintah Daerah.” Fiat Justisia 10(3):569-86. doi: 10.25041/fiatjustisia.v10no3.794.

Pamungkas, Bayu Aji, and Sri Handayaningsih. 2014. Implementasi Back Office Aplikasi M-Goverment. Jurnal Sarjana Teknik Informatika. 2 (1), 731-737 
Prianto, Hendri, and Rati Sumantri. 2020. "Tantangan Penerapan Inovasi Di Kota Semarang.” Sprit Publik Jurnal Aministrasi Publik 51(1):39-49.

Puspasari, Bela, and Dekki Umamur Ra'is. 2019. "Inovasi Anjungan Tunai Mandiri (ALM) Dalam Meningkatkan Pelayanan Publik (Studi Di Kelurahan Belimbing Kecamatan Belimbing Kota Malang)." JISIP : Jurnal Ilmu Sosial Dan Ilmu Politik, 8 (2):70-77.

Ramadhan, Mirza Faruz. 2016. Inovasi Pelayanan Publik (Studi Deskriptif Tentang Program Layanan Tujuh Menit ( LATUM ) sebagai Upaya Peningkatan Kualitas Pelayanan i Kantor Badan Pertanahan Nasional Kota Surabaya. Kebijakan dan Manajemen Publik, 4 (1): 1-10

Rusmiarti, Dewi Ariningrum. 2015. "Analysis of the Diffusion Innovation and the Development of Work Culture in Bureaucratic Organization." Jurnal Masyarakat Telematika Dan Informasi, 6 (2): 85-100.

Wulandari, Herlina. Afifuddin, and Suyeno. 2020. "Efektifitas Inovasi Program Pelayanan Publik Berbasis E-Government (Studi Kasus Aplikasi "Dr. Kepo" Dokter Kependudukan Online di Dinas Kependudukan dan Pencatatan Sipil Kabupaten Gresik). Jurnal Respon Publik, 14 (3): 27-35

\section{Peraturan}

Keputusan Menteri Negara Pendayagunaan Aparatur Negara (Men-PAN) Nomor 81 Tahun 1993

Surat Keputusan Kepala Disdukcapil No. 14 Tahun 2019 tentang Pembentukan Anggota Tim Digi Mobile

Kepmenpan No. 63/KEP/M.PAN/ 7/2003 tentang Pelayanan Publik

Profil perkembangan kependudukan Kota Pariaman Tahun 2019,

Peraturan Mentri Dalam Negeri Rebuplik Indonesia No 7 Tahun 2019 Tentang Pelayanan Administrasi Kependudukan Secara Daring

Peraturan Walikota Pariaman No. 55 Tahun 2016 tentang Kedudukan dan susunan Organisasi Perangkat Daerah Kota Pariaman

Peraturan Daerah Kota Pariaman no. 8 Tahun 2018 tentang penghapusan denda pengurusan dokumen kependudukan

Permenpan dan Reformasi Birokrasi No. 30 Tahun 2014 Tentang Pedoman Inovasi Pelayanan Publik. 
Undang-Undang Nomor 23 Tahun 2014 tentang penyelenggaraan pemerintahan

Presiden Nomor 6 Tahun 2001 pada tanggal 24 April 2001 tentang Telematika (Telekomunikasi, Media dan Informatika) 